\title{
Caught on the Back Foot: Epistemic Inertia and Visible Music
}

\author{
Philip Tagg \\ Visiting Professor in Musicology \\ Universities of Huddersfield and Salford \\ philtagg@gmail.com
}

\begin{abstract}
This paper explores the position of popular music studies thirty years since the formation of the International Association for the Study of Popular Music. Founder member of the association, Phillip Tagg, discusses what issues need to be addressed in the field, and how could they be better understood. Areas investigated include interdisciplinarity, interprofessionalism, epistemic intertia and invisiblemusic. The paper concludes that musicologists working in popular music havefailed to make such inroads into conventional musicology that popular music and art music are treated equally. It also questions why researchers from non-musical backgrounds still struggle to address the music of popular music studies, and offers solutions. It finally suggests that we are in a new stage of musical culture, in which audio-only/visible music has been replaced with audiovisual/invisible music, and that as a result popular music studies needs to engage further with music and the moving image.
\end{abstract}

Keywords: IASPM, interdisciplinarity, interprofessionalism, epistemic inertia, invisible music, audiovisual

\section{Introduction}

It's thirty years since the Cambridge University Press journal Popular Music first appeared, thirty years since IASPM was founded. This isn't the first time l've felt the need, to comment on the development of popular music studies (Tagg, 1981, 1983, 1985a, 1985b, 1997, 1998a, 1998b, 2001a, 2001b, 2001c). My question today is: what sort of issues do I think IASPM, aged thirty, needs to address and what sort of constructive suggestions, if any, can I come up with?

In this paper l'll focus on two interrelated areas where it seems to me that IASPM has been caught on the back foot. l've called those areas epistemic inertia and invisible music. Since I won't be able here to deal with some areas of these topics in detail, I'll make frequent reference to relevant work providing more substance in terms of theory, method and argumentation, as well as of exemplification and empirical information. However, in order to contextualise those concepts, I first need to summarise the basic rationale behind IASPM's main aims, at least as they were initially conceived. In 1981 IASPM's aims and objectives were formulated in terms of an interdisciplinary, international and interprofessional organisation, for the following sorts of reason (Tagg, 1981, 1989).

Interdisciplinarity was included because it's impossible to understand much about music without considering it from the viewpoints of areas such as music making, 
musicology, ethnomusicology, anthropology, psychology, sociology, acoustics and bioacoustics, neurology, technology, electronics, economics and politics Internationalism or interculturalism, were also considered important, the latter denoting a larger set of combinative activities of which internationalism is but one subset. Many types of music are disseminated globally and it would be as misleading as it would be undemocratic to exclude from serious consideration any set of musical practices associated with any population, be it defined according to social, economic, ethnic, cultural or any other similar set of criteria.

Interprofessionalism was addressed because it is impossible to understand much about music without considering it in relation to the multitude of functions it can fulfil, or without consulting a wide range of those who, in one way or another, mediate musical experience, such as composers, lyricists, musicians, vocalists, technicians, managers, producers, DJs, venue owners, journalists, teachers, collectors, fans, listeners, dancers, those working in audiovisual and/or broadcast media, in sport, in advertising, in cultural policy making or implementation.

\section{Interdisciplinarity and interprofessionalism}

The fact that the 2011 IASPM conference was held in South Africa, and that IASPM has members in all five continents, suggests that the association has had some success with its international goals. Some exceptions are a lack of members in China, India, Russia, Central Asia, Southeast Asia, the Arab world and Germanophone Europe. IASPM has also managed to interest scholars from quite a broad range of disciplines, even though some (e.g. acoustics, architecture, dance studies, electronics, medicine, neurology, theology) are either underrepresented or absent. If IASPM were able to recruit members from the sort of areas just mentioned it would certainly become more multidisciplinary but not necessarily more interdisciplinary, because the latter implies ongoing interaction inter-disciplinas, not just the occasional interchange between individuals who share an area of study in common but who generally stick to the familiar approaches of their own discipline. Projects involving ongoing collaboration between disciplines are still rare in IASPM but the fact that they now exist is, I think, a very encouraging sign. Two examples of such projects are The Post-Socialist Punk group and The Sound in Media Culture project (Gololobov, 2011; International Research Project, 2011).

In terms of interprofessionalism it's probably safe to say that IASPM has had less success. That's mainly due to interrelated epistemological and institutional factors that l've tried to explain on numerous occasions throughout the history of IASPM. For example, in an email dated 23 June 1995, in answer to my question 'what do you think is currently wrong with IASPM internationally?', Franco Fabbri, referring to the general intellectual direction taken by IASPM internationally and by the journal Popular Music, wrote: "[M]usic and musicians seem to have become some kind of troublesome appendage to popular music studies"... "Where is music and where are the musicians? Can researchers learn something from them, or are musicians some kind of unnecessary appendix of popular music studies?". It should be remembered that Fabbri was a founder member of IASPM with experience as guitarist (rock and classical), composer, computer network company manager, ex-record company organiser, cultural policy-maker, chairperson of IASPM Italy and music journalist. In 1995 I heard similar comments from Chris Cutler, Reebee Garofalo, Charles Hamm, Gerard Kempers, and from other intellectually competent musicians who were once actively involved in IASPM internationally but who by the mid 1990s had become disenchanted with what they saw as a hierarchy of politically cool but epistemologically restrictive hierarchy of ideas, discourses and approaches (Tagg, 2001c, p. 1).

If it were just the simple fact that musicians, film composers, games audio programmers, band managers, dancers, backing vocalists, media journalists and other 
music industry professionals, don't generally hang out in universities and consequently have little chance of financing a trip half way round the world to attend an IASPM conference, that would at least be an identifiable logistic issue that could be addressed. However, the problems go deeper than that, right to the heart of the Great Epistemic Divide in European culture between notions of art and science, subjective and objective, poïesis and aesthesis. (Tagg, forthcoming) By aesthesis, I mean the perception of music rather than to its production or construction, the opposite of poïesis relating to the making of music rather than to its perception. Poïetic qualifies the denotation of musical structures from the standpoint of their construction rather than their perception, for example con sordino, minor major-seven chord, augmented fourth or pentatonicism, rather than delicate, detective chord, allegro, high-heeled saxophone or spoilt princess voice. For more about music and the Great Epistemic Divide, see Tagg (forthcoming).

It is not possible to deal here with such major issues of knowledge, skills and experience. I have tried to bring all these ideas together in Music's Meanings (Tagg, forthcoming), particularly in chapters 2 and 3 . The contradiction between cross-domain representation and epistemic diffraction is discussed in further detail in the video Epistemic Diffraction or Integration (Tagg, 2011c, 0:00-08:47 and 14:33-19:06). It is a contradiction that underpins most of the problems I deal with in this presentation. Understanding its dynamic helps lay bare the disciplinary inertia and conceptual conservatism that not only characterise many institutions of musical learning but which can also obstruct interdisciplinary activity in IASPM.

\title{
Scotch snaps and 'one-man interdisciplinarity'
}

The video mentioned above explains the wider sort of contradiction polarising, on the one hand, the intrinsically holistic and synaesthetic type of expression that is music and, on the other, the plethora of separate disciplines related to the understanding of music as a social and cultural phenomenon. The Scotch Snap video, below, illustrates another set of problems at the heart of the same general contradiction:

\author{
Video Example 1: \\ Scotch Snaps: The Big Picture [1:14:54]: \\ www.youtube.com/watch?v=3BQAD5uZsLY
}

I made this video because, while writing the 'Simple sign typology' chapter of my 'musicology for non-musos' (Tagg forthcoming), I needed to explain how spoken languages influence musical rhythm, in particular how specific rhythms in music let listeners know the socio-linguistic location of the music they're hearing. The Scotch snap sprang immediately to mind as a clear example of this sort of sign type which I call, not very imaginatively, a 'language identifier'. Although structurally (poïetically) defined in various musical reference works, the Scotch snap's sociolinguistic, historical and cultural connotations are rarely, if ever, mentioned. Video example 1 was produced to make semiotic sense of that language identifier. One point in need of explanation was, as demonstrated in the fact that language identifiers need no actual words to be sung or spoken to function as such.

\author{
Video Example 2: \\ Norman Blake: 'Randall Collins' (extract): \\ www.tagg.org/Clips/RandallCollins.mp4
}


Several parameters of expression - instrumentation, metre, tempo, mode (tonal vocabulary) etc. - can help listeners identify example 3 as British or North American rather than as, say, Turkish or West African, but the snap zooms more closely in on its identification as music from regions where either Gaelic or English is mother tongue. That sort of observation needed substantiation in a form allowing musos and nonmusos alike to understand answers to the following sorts of question in Example 2.

1. What is a Scotch snap?

2. Why is it called 'Scotch' rather than Gaelic or English, given that the latter languages, not just Lowland Scots dialects of English, use the rhythm extensively in speech and song?

3. Why does spoken English, unlike most other European languages, contain so many snaps?

4. Why are snaps so common in music associated with cowboys and the Wild West?

5. Why did Dvořák use the Scotch snap in his New World Symphony and why did he think that 'Negro melodies' in North America resembled Scottish music?

6. Is Professor Willi Apel (in the Harvard Dictionary of Music, 1958) right in stating that the snap 'is a typical feature of Scottish folk tunes, of American Negro music and of jazz'?

7. If Apel is right what is African about the snap?

8. Why did Apel characterise snaps as a typical of English baroque music (e.g. Purcell)?

9. How many people of which socio-economic background in Britain ended up in which parts of North America between 1607 (the year of the Jamestown Landing) and 1865 (the end of the US Civil War), and what contact did they have with people of African origin deported during the same period into slavery?

10. Which of those British and African populations brought along the snap, or anything resembling it, in their cultural baggage?

11. Why, starting in the eighteenth century, did Scotch snaps disappear from music thought of as 'English' rather than as Scottish, Irish or otherwise 'Celtic'?

12. What on earth does 'Celtic' actually mean?

13. What is 'Celtic music' and why is music of English origin (the music of 'Early America', never referred to as 'English') included in the 'Celtic Music Fan' website's preferred repertoire (along with music from Scotland, Ireland, Brittany, Galícia and Cape Breton)?

14. Can items of musical structure like the Scotch snap, or the backbeat (see Tamlyn, 1998), be understood solely in terms of either ethnicity, class, gesturality, etc., or do they embody aspects of these and other factors that change over time and under different circumstances to represent different identities of ethnicity, class and so on?

Any serious attempt at answering these fourteen questions arising from just two notes involves a whole range of disciplines and specialisms. Apart from musicology, my own disciplinary starting point and home territory, I had to enter areas of knowledge where I have little or no formal qualifications, such as phonetics, linguistics, comparative linguistics, rhetoric, English language, English history, Celtic studies, African studies, African-American studies, toponomy, geography, anthropology, social history, history of ideas, history of emigration and diasporas, cultural studies, communication theory, demographics, and political economy. To make matters worse, I have little expertise in the popular music of rural Britain or Appalachian America, and even less in the musics of West Africa. Given the difficulty of one person having competence in the majority of disciplines relevant to the fourteen questions just listed, I should have perhaps stuck to strictly musicological matters and left all the history, 
politics, linguistics, African studies and so on to qualified experts in those areas. I didn't. I've often been criticised for driving disciplinary vehicles for which I have no valid license.

I've also been called naïve when l've used musicology to question notions like 'black' and 'white' music as in the 'Open Letter about "Black" and "White" Music' (Tagg, 1989 , p. 285-298), the territory of experts in African-American studies. This criticism was also raised when I used my daughter's experience as an organiser of alternative raves during the 1990s as circumstantial evidence for musicological ideas about radical changes in socialisation patterns among young Europeans, as in 'From Refrain to Rave: the Decline of Figure and the Rise of Ground' (Tagg, 1994, p. 209-222). This could be seen as the territory of experts in youth subculture. I'll doubtless receive the same sort of objections to my Scotch snap video. The problem is that it would have been virtually impossible to involve certified experts in all of the disciplines necessary to a full understanding of Scotch snaps. That means I have to decide whether to stick to my home subject or to venture out into less familiar territory, with of course the occasional request to colleagues who can act as guides in other disciplines. If I never venture into foreign disciplinary territory l'll be automatically reinforcing the epistemic diffraction that, as explained in example 1, contradicts the holistic, synaesthetic and cross-domain nature of music as a specific mode of human communication. That's basically why I tend to follow the 'one-man interdisciplinary' option, even if I risk incurring the wrath of colleagues in other areas of expertise. Another reason is that challenges, naïve or otherwise, to the intellectual assumptions and canons of established disciplines, can sometimes be salutary. At least that is the case with several challenges and critiques of musicology coming from both inside and outside the discipline.

\section{On the back foot (1): epistemic inertia}

I think that conventional musicology is to a significant extent a conceptual disaster zone. It may have developed valid theories about harmonic narrative in European art music, but it has, in my view, been intellectually about as open-minded as religious fundamentalism in dealing with anything outside its own restricted frames of reference. Despite the radical challenges presented by first ethnomusicology over a century ago, then by the sociology of music, and latterly by popular music studies, its followers still often seem to believe in universal values of aesthetic excellence based on a canonic repertoire of work used by a minority of the population over a very limited number of years in the world's smallest continent. Many of these followers hold articles of faith about 'absolute' music transcending sordid social realities outside the 'higher art' of lonely geniuses whose 'masterworks' are authoritatively fixed in the written score. The fact that sound recording has existed since 1877, and that it became the twentieth century's most important medium of musical storage and dissemination, does not seem to matter. Nor does the fact that first coil microphones and electrically amplified recording, then instrument amplification and multi-channel recording, then audio synthesis, then sampling, then digital sound treatment and so on, all radically altered and expanded music's means of expression, not least in the popular field. As I have written elsewhere,

\footnotetext{
Philip Hayward spoke eloquently for greater involvement in IASPM from musicians and musicologists, a cause I have tried to champion for many years now. One obvious reason for the dearth of music-immanent studies of popular music is, as Hayward rightly pointed out, the dogged conservatism and, I would say, suicidal elitism of many traditional departments of musicology (Tagg, 1997, p. 6).
}

I am by no means the first and definitely not the most vociferous critic of conventional music studies. For example,Hindemith said as early as 1952 
It is the average teachers' unshakable belief in the stiff corset of schedules that is supposed to keep their pedagogic posture in shape, and they do not want to see that corsets are neither salutary nor fashionable ... [It is absurd to believe that] 'an outdated system can produce composers and theorists of a quality that our ... society has a right to demand. (1961, p. 218).

Ethnomusicology, not least through its reliance on sound recording and on aurality, as well as through its intrinsically relativist approach to music cultures (vergleichende Musikwissenschaft), posed a serious threat to conventional musicology; but it has, as a subdiscipline under musicology, often been marginalised as a sort of exotic aural exception to the Central European scribal rule. There is also the risk, I fear, that 'musicology of the popular' may meet a similar institutional fate. To use a South African simile, it's a bit like the pass laws under apartheid, where the popular majority had to carry identification around with them at all times while the privileged minority did not. Musicologists of the popular are identified as belonging to either 'ethnomusicology', or 'the sociology of music', or 'popular music studies', in other words to subspecies inside the supposedly superior genus of just 'music' or 'musicology', which paradoxically sees no need to identify itself as relating specifically to European art music from 1600-1940, and to little or nothing else.

In the 1980s, some forward-thinking European and North American universities, wishing to be seen as responding to popular demand and needing, for financial reasons, to increase student numbers, took on popular music scholars like Peter Wicke, Richard Middleton and myself. After working almost forty years each as token popular music representatives in our discipline, the three of us now seem largely to agree that our attempts to reform musicology have so far had very little institutional effect. In fact, if my interpretation of conversations in 2011 with those two respected colleagues is anything to go by, officially recognised institutions of musicology have more often than not reverted to their European-art-music-centred business as usual, keeping ethno, jazz, popular and other exceptions to their rule (itself an exception to the rule in extramural reality) at a safe distance out in the institutional margins. Very few concrete steps have been taken to integrate those 'other' areas into the discipline in a process of reform and modernisation.

Such institutional failure in no way means that attempts to develop a musicology of the popular have been in vain, nor that musicology is intrinsically useless as a discipline. On the contrary, popular music studies have, for better and for worse, made a substantial contribution to the development of various types of 'alternative musicology', as can be easily illustrated from a web search for alternative musicology. I should also add, on a more personal note, that I have recently been greatly encouraged by the increasing number of younger scholars who seem to be familiar with my work and by the frequency with which I am asked to speak in contexts of considerable disciplinary, professional and cultural diversity. As for musicology itself, I am still convinced that the discipline has a central role to play in combatting the dual consciousness and epistemic schizophrenia that continue to antagonistically polarise notions of subjectivity and objectivity, and which impede the development of selfawareness and, by extension, democratic forms of government (see the Preface, as well as in Chapters 2 to 4 of Tagg, forthcoming; and Chapters 1 and 2 of Tagg and Clarida, 2003, p. 4-92). However, before musicology can rise to such adult challenges it needs to grow up, to face extramural reality and, as I try to explain next, to set its conceptual house in order.

From my viewpoint as a musicologist of the popular, the most disturbing aspect of conventional musicology is its chaotic conceptualisation of musical structuration, exactly the sort of intellectual activity for which it is supposed to be expertly equipped. Not only has the discipline failed to either accept or develop adequate terminology for designating differences of elements such as timbre, vocal persona or acoustic staging, 
it has also been slow to develop useful ways of conceptualising periodicity and metricity. Syncopation and polyrhythm are two problematic terms. Syncopation can only exist in monometric music. It is a pretty meaningless term for the diversity of bimetric or polymetric musics found in Africa, the Caribbean and Latin America. Polyrhythm, more than one rhythm at the same time, is often inaccurately used to mean polymetricity, more than one metre at a time. (Lacasse, 2000). Most disconcerting, however, is the fact that conventional musicology does not even seem to have a viable vocabulary for the rudiments of an activity at which the discipline is assumed to excel: designating the tonal properties of musical structure. To put not too fine a point on it, words like tone, modality, polyphony, counterpoint, cadence, dominant, not to mention tonality itself, are used in what I can only qualify as an ethnocentrically muddle-headed manner. Since there is no room here to substantiate that serious accusation, readers are referred to the first few chapters in Everyday Tonality (Tagg, 2009a) for a more detailed discussion of such problems.

It was these very issues that caused me to write Everyday Tonality. Conventional musicology's concepts are frankly often either useless or misleading if you want to explain the 'La Bamba' loop, or 'interrupted' cadences that are in fact final, or aeolian shuttles, or bimodal tunes or chord sequences, or decidedly tonal tunes with no clear single tonal centre. (See in particular Tagg, 2009a: 'Tone, tonal, tonality' p. 22-26), 'Polyphony: three meanings' p. 81-82; 'Classical harmony', including 'Triads and tertial harmony' p. 93-95; 'Non-classical' harmony p. 115-136; 'One-chord changes' p.159-171; 'Chord shuttles', especially the passage about Pink Floyd's Great Gig In The Sky p.179-181 and Human League's Don't You Want Me Baby p.191-193; 'Modal loops and bimodality' p. 217-240, in particular the passages about 'uninterrupted' cadences and Carlos Puebla's Comandante Che Guevara under 'Aeolian and phrygian' p.227-234). Also relevant is the video Dominants and Dominance (Tagg, 2009b).

Conventional musicology's institutional and conceptual marginalisation of musics other than the Euroclassical may, I think, be one key in solving IASPM's problems with the epistemology of music. That's why, in a book subtitled 'musicology for non-musos' (Tagg, forthcoming), I've tried to sort out underlying epistemic assumptions in our culture about 'what music can and can't do'. This work involves explanations of why some cultures have, and others don't have, a word distinguishing what we call 'music' from other modes of expression with which it often co-occurs (e.g. dance and drama). Understanding such conceptualisation, or lack of it, provides, I believe, important insights into our own (Western) culture and to what we regard as music's role within it. In the book, I try to explain how a certain type of music from Central Europe became 'classical', as well as how and why it was institutionalised in seats of musical learning. I also try to deal with the social and political reasons for the development, in European and North American institutions of musical learning, of metaphysical canons and ethnocentric notions of universal aesthetic excellence. These three basic issues of musical epistemology, what is 'music' and what is music; how did classical music become 'classical' (Ling, 1989); and what values were established for which reasons in official institutions of music, need to be grasped, I think, by anyone claiming to deal seriously with any aspect of music, regardless of whether musical structure features centrally, marginally, or not at all, in their study. Viewing conventional music studies, as they are still largely practised in Europe and North America, from historical and anthropological perspectives, reveals the sociocultural specificity of power agendas lurking behind the mask of 'superior' art. I would not need to mention this power issue if I thought it had no relevance to popular music studies; but I think it does. I'm referring in particular here to anglocentric 'rockology' and of its penchant for traditions of literary criticism and postmodernist thought (such as scholastic 'poststructuralism'), in other words what Mattelart \& Neveu (1996) call, in French, La French theory. 
I have discussed these issues in Tagg \& Clarida (2003, p. 57-89), in particular in the sections 'The institutionalisation of rock', 'Pomo-rockology, consumerism and the "liberation of the id"', and 'Music: a troublesome appendage to cultural studies'. A shorter account of the same problem complex starts half way through Chapter 3 in Tagg (forthcoming). Johnson summarises one key problem in 'Cultural Theory' as follows: '[b]y the 1980s, theory was becoming a new scholasticism, deducing "the world" from a set of a priori suppositions... [S]ocial practices, irrespective of their shape, were hammered into the spaces made by theory'. (Johnson, 2009, p. 2).

It should be clear that no-one needs to be notationally literate or to know what a diminished seventh is to grasp the issues just raised about the epistemology of music. Even the gist of the section bewailing the conceptual chaos of conventional musicology ought to be understood by all, despite the few poïetic details listed, for the benefit of muso readers. If, as l've just suggested, both musos and non-musos could grasp the epistemic idiosyncrasies of music and its institutionalisation in Western traditions of knowledge, we would, as popular music scholars, find it easier to identify the underlying problems in our field of study and, consequently, to come up with viable strategies for solving them. We may have made a little progress in that direction but I think we are still all too often caught on the back foot, expecting the ever-changing realities of our field of study to conform to the familiar patterns of intellectual activity we inherited growing up inside our disciplines. Musicologists of the popular fall into the trap of epistemic inertia when, for example, they use the dualism TONAL - MODAL, as if the 'modal' tonality of styles like rock, blues or son were not tonal and as if works in the Viennese classical idiom, mostly conceived in the ionian mode, were in no way modal. It just makes no sense. There's simply no good excuse for using terms that make nonsense of the way in which sounds are organised by the majority of musicians producing the majority of music heard and used by a majority of the world's population.

Nor does it make sense when non-musos present claims of musical incompetence as excuses for avoiding issues of musical structuration. There are two reasons for rejecting this particular variant of epistemic sloth. One reason -the value of vernacular aesthesic descriptors and their potential for reforming musicology- is too complex to discuss here in detail. For explanations see Tagg (forthcoming), especially the sections 'Structural denotors' and 'Skills, competences, knowledges' in chapter 3; 'Aesthesic focus' near the start of chapter 6; and 'Aesthesic descriptors' in the middle of chapter 10 . The other is very simple. It is that anyone can unequivocally designate any item of musical structuration that occurs in a digital recording. All you need is playback equipment and software featuring (as they all do) a real-time counter. For example, as shown in Figure 1, there's no need to refer to the archetypal spy chord at the end of the James Bond theme as 'E minor major nine', or as 'a B major triad over an E minor triad', or to call it 'the chord on beat 3 of bar 57', nor is it necessary to denote it in terms of 'a clean Fender sound with slight reverb accompanied by vibraphone', however correct any of those poïetic descriptors may be. That it is the only chord at 01:39 in the recording under discussion is enough to designate it unequivocally.

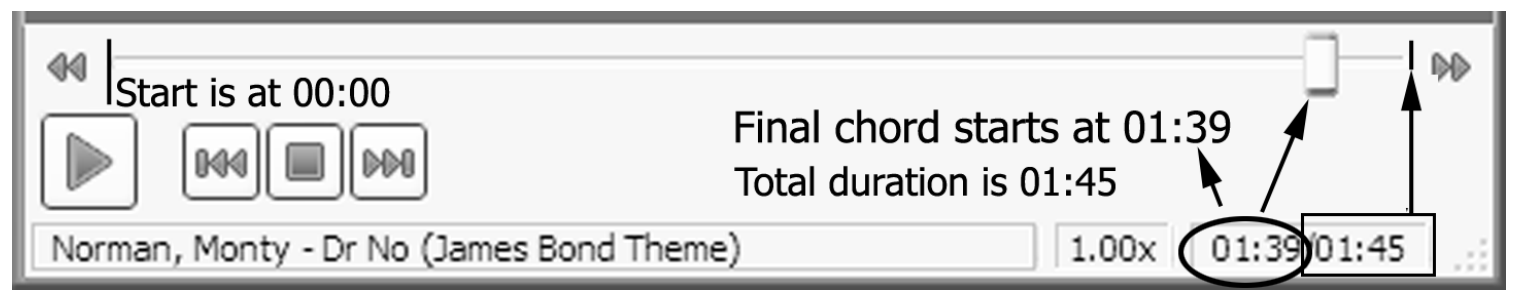

Figure 1 - Timecode for the final chord in the James Bond theme (VLC display) 
Of course, reference to the relevant recording must be provided. In this case it's the audio file at tagg.org/audio/DrNoBondVinyl.mp3. The duration of the James Bond Theme at YouTube/iTunes is 1:48, not 1:45 as in Figure 1 ('my' version). This discrepancy is due to the fact that the audio file on which 'my' version is based is an analogue-to-digital transfer from a vinyl album (Norman/Barry, 1962) and that I trimmed its initial and final silences to 0.6 " and 1 " respectively, whereas the iTunes file starts with 1.3" and ends with almost 3 " of silence. This means that timings in Figure 1 are 0.7" ( $\approx 1$ ") earlier than in the iTunes file. 'Bar 57': based on bar count in common time (no change of metre).

In addition to unequivocal timecode placement (the starting point of a particular event in a recording), there's nothing to stop anyone from referring to musical sounds in terms of paramusical synchronicity. Three fictitious examples serve to illustrate this point, [1] the singer's contented growl on the last 'oh, baby!' in verse 1 (at 00:31 in a pop song); [2] the distant screeching just before she pours poison into his whiskey (at $1: 02: 15$ in a feature film on DVD); or [3] the drum pattern that synchronises with the quick zoom-in on to the lead vocalist (at 02:20 in a music video). Nor is there any good reason why musical events cannot be given aesthesic rather than poïetic labels, for instance (returning to the James Bond Theme), [1] the twangy guitar at 00:07; [2] the danger stabs at 01:33 and [3] the final spy chord at 1:39. Those structural designations, all accurate and unequivocal, can be made by anyone capable of hearing a musical event, of hitting the pause button at the appropriate moment and of noting the timecode displayed at that point. No formal musical training is required and there is no good reason for any seeing and hearing person to be caught on the back foot by changes in media technology that took place over fifteen years ago and which put the verbal denotation of musical structure within the grasp of anyone, muso or non-muso (Tagg forthcoming: Chapter 7).

\section{On the back foot (2): music and the moving image}

Musicology's apparent lack of interest in reforming its concepts of structural designation to accommodate the sonic practices of the popular majority was one example of epistemic inertia putting popular music studies on the back foot. Another example, just discussed, was the case of non-musos avoiding the 'music' in 'popular music studies' on the obsolete excuse of musicological incompetence. This final section of the presentation sees IASPM on the back foot in responding to another technological change: that from audio-only commodity with visual music, to audiovisual commodity with invisible music 26. (Tagg forthcoming: Chapter 13; Tagg, 2011a).

Westerners hear on average over four hours of music every day (Tagg forthcoming: Chapter 1). About one half (about 2 hours) of this daily dose of music is heard in conjunction with moving images, for example as underscore or as theme music for films, DVDs, TV programmes, adverts, jingles, trailers or games. The vast majority of that music is invisible in the sense that we don't see anybody making (or even pretending to make) the sounds we actually hear. Invisible music is a term borrowed from Austrian twelve-tone and film composer Hanns Jelinek (1968). Music programming on TV, music-based games, adverts showing musical performance and musical films are all the exception rather than the rule. Assuming that the small proportion of visible music on TV is less than the average daily dose of invisible media music heard for example via games, DVDs and video files using consoles, computers and smartphones, two hours should be seen as a conservative estimate of the average daily dose of invisible music heard by the average Westerner in connection with moving images. If you also consider music for religious and other ritual functions, for the stage, for dancing, on the radio, on personal stereos, through speakers in bars, cars, cafés, trains, planes or shopping centres, it becomes obvious that most music, not just most music heard in conjunction with moving images, is invisible. In these 
contexts hearing does not necessarily involve listening. In the theatre, of course, music-making is hidden in the orchestra pit under the stage. In churches the organist is usually placed in an organ loft or in a similar position out of sight.

If music in everyday life is overwhelmingly invisible for the majority of those who hear and use it, it's not unreasonable to ask why music studies, including popular music studies, have been so dominated by visible music, mostly in terms of vocal or instrumental performance (occasionally also as sound engineering), but much less, and much less visibly, as composition or arrangement. That anomaly can be partly explained through deconstruction of the absolute music aesthetic (Tagg, forthcoming: Chapter 3), and through a critical examination of music education's lopsided concern for poïesis at the expense of aesthesis. But the anomaly is also caused by the simple fact, obvious to the point of tautology, that, in a scopocentric culture such as ours, visible music draws much more attention to itself than does invisible music, no matter how important or omnipresent the latter may be. The scopocentric, relates to assuming, usually implicitly, other types of expression than visual to be of lesser importance (Johnson, 2009, p.2-6). Scopocentric should not to be confused with the related term graphocentric, coined by Jean-Jacques Nattiez (1990) meaning assuming written or other graphic signs, typically musical notation, to be of greater importance than nongraphic ones).

With visible performance we can immediately identify the sounds we hear with what we see producing (or pretending to produce) those sounds, one sense of perception confirms the other. With invisible music, on the other hand, we see no performance of what we hear, we have no visual confirmation of the production of those sounds. Without that visual crutch we easily become unaware of the presence of music, typically when it is heard as underscore in a film or as a loop in a computer game. It's almost as if not seeing the music prevents us from consciously acknowledging its existence as music, no matter how much of it our ears and brains process on a daily basis. This scopocentric need for visual concretion of what we hear in order to consciously register its existence and, consequently, its potential effects, is exacerbated by another, even more prosaic, issue.

Although film and audio recording both started in the late nineteenth century, their technologies of storage and distribution developed quite differently. While the number of households containing a gramophone and audio recordings increased dramatically in the 1920s and after World War II, it was not until the 1980s that videocassettes started to occupy significant shelf space in the average Western home, and not until around 2000 that DVDs started to do the same. That means several generations during which phonograms dominated the home entertainment market as storage and distribution medium, the last thirty of those years coinciding with the global spread of the pop or rock related styles which constitute the core repertoire around which popular music scholars, at least in the anglophone world, have tended to congregate. These are in other words musical practices linked to a period of audio-only technology during which the recording industry used 'the act', as in 'stage act' (visible music), as focus for product identity and marketing. The audio-only commodity was visibly linked to performers while music created for audiovisual products (film, TV, games, etc.) was linked to the visual aspects of those products, almost never to anyone identifiable in the musical production process. The viability of this observation can be tested by looking at Figure 2 below, showing 29 individuals all of whose music has been widely disseminated.

My hypothesis is that it will be easier to identify the 'acts' (visible performers associated with audio-only products), and more difficult to recognise composers of music for moving images (invisible music for audiovisual productions). Whatever the reasons may be for IASPM'S relative lack of interest in music for film, TV and computer games, it should be clear that audiovisual products and services (including DVDs, internet downloads, and their invisible music) have long since replaced their audio-only 
counterparts as the mainstay of the home entertainment industry. Moreover, affordable digital video cameras and audiovisual editing software have brought simple film production within the reach of a much larger proportion of the population than could afford to run an audio-only home studio in the 1970s or 1980s. Music has not become less important: it has just moved house, so to speak. While visible music has in recent years focused more on live performance and less on audio-only recordings, invisible music has also, with the advent of computer games and sites like YouTube, become increasingly widespread. However, invisible music is no longer merely an essential ingredient in ready-made audiovisual entertainment products - it has played that role ever since the advent of the talking film. It has now also become an integral part in processes of popular multimedia production. As Bob Davis (Huddersfield and Leeds), put it when observing the creative habits of his music students, 'it's not so much "I think, speak or play, therefore I am" as "I make videos, therefore I am"'. 'Cogito ergo sum' has become 'Imagines creo ergo sum'.

One reason why it's so important to address the 'invisible music' aspect of IASPM's being caught on the back foot is that music and the moving image is an area of study providing ideal opportunities for resolving some of the deeper epistemological problems that have dogged popular music studies since the outset. I base this opinion on experience from running Music and Moving Image courses over a period of seventeen years (1993-2009). I have documented the rationale, aims, methods and content of those courses elsewhere, (Tagg, 2009d; Tagg, 2011a; Tagg forthcoming: chapter 13). I will restrict myself here to a very brief sketch of issues directly relating to IASPM's basic epistemological problem (Tagg, forthcoming: Chapter 3) of integrating musical and metamusical types of knowledge.

Music and the moving image is a subject of equal interest to those with and those without formal training in music. Although I was attached to university schools of music, a significant number of students on my courses came from subjects like cinema and communication studies. This mixture of musos and non-musos on the same course has three distinct advantages. Firstly it rhymes better with the reality of audiovisual production where musical experts (such as composer and music editor) and others (director, scenographer) have to collaborate. Secondly, musos have to learn how to talk about their ideas in ways that non-musos can understand and to decipher what non-muso collaborators say they want by way of music. Thirdly, non-musos who

want to work in the audiovisual sphere, have to rely on their own aesthesic competence in music and learn how to give composers and music editors a coherent and comprehensible brief (Tagg, forthcoming: Chapter 5).

These first three points have further implications. Musos have to learn the rudiments of cinematographic terms and practices, while non-musos have to plunge into the weird world of musical thought. Musos have to learn that music serves other purposes than those extolled by their music-making peers, that their art communicates more than just itself, and that visual narrative rarely aligns squarely with musical patterns of change, continuation and finality. Music videos are of course exceptions to this rule. Non-musos have to stop pretending they are unmusical and learn to trust their own ears as well as eyes. They also need to understand something of how musicians tend to think and act, and to grasp the potential of music's main parameters of expression (Tagg, forthcoming: Chapters 8-11). Both musos and non-musos involved in audiovisual production need to have realistic notions of what music can and cannot do, and of how it can communicate things other than itself. They also need to be aware that their own musical experience, however intense, is not necessarily that of their prospective audience. 
Figure 2: Who's Who quiz of visible and invisible music

Link to: http://www.tagg.org/xpdfs/IASPM1106Pix.pdf

Answers below

These points are learnt mainly through hands-on coursework involving dialogue between musos and non-musos in two assignments, One is musical mood comparison between silent film and recent feature film, a group project in which musical moods from the silent film era are compared with the same moods in films from more recent years; Cue list and analysis of a feature film, an individual project involving connotative feedback sessions in class, the preparation of graphic scores, and discussion of music's meanings and functions in conjunction with the visual and verbal aspects of the production. (Tagg, 2009; Tagg, 2011a; Tagg, forthcoming: Chapter 13). One of the most important lessons I learnt from running these courses is that the aesthesic descriptions of music offered by non-musos can help fill some of the gaps in musicology's vocabulary of structural denotation, especially in the areas of timbre, texture, type of movement and acoustic staging. It has also been gratifying to see how willing most musos are to abandon their guild mentality, including any notions of 'absolute' art, to make their music actually work in an audiovisual context, as well as to see the readiness with which most non-musos embrace lateral, connotative, musogenic thinking in efforts to understand how audiovisual production can be both deeply and subtly enriched by the intelligent use of music.

It is for these reasons that I think IASPM's relative lack of interest in invisible music, whatever its causes, constitutes a sadly wasted opportunity to address, and by extension to solve, core epistemological problems in our field of studies.

\section{Conclusions}

In this presentation I've tried to clarify three ways in which I think IASPM has been caught on the back foot.

1. We 'musicologists of the popular' have failed, at least in certain parts of the world, to make any substantial inroads into the institutional strongholds of our discipline. This failure includes our sometimes uncritical use of conventional musicology's terminology to inadequately denote, and thereby falsify the nature and functions of, many structural practices in many types of popular music.

2. Some non-musos still offer the obsolete excuse that they cannot adequately designate musical structures despite technological developments having allowed them to do so since the mid 1990s. This insistence helps reinforce the unfortunate divide between knowledge about music and musical knowledge, and furthers the notion that the music in popular music studies is incidental.

3. IASPM members' relative lack of interest in invisible music may well derive from habitual and unreflective belief in the permanence of the audio-only/visible music stage of music history linked to the heyday of pop, rock and youth cultures in the West, even though it has been culturally, financially and technologically superseded by an audiovisual/invisible music stage. Whatever the case, that lack of interest shows no awareness of, and thereby effectively denies, the obvious advantages that working with music and the moving image can provide in solving core epistemological problems in our field of study. 
The final 'back foot' is my own because my involvement in IASPM has repeatedly caught me unawares. Trawling through all the papers l've produced about IASPM over the years, I realise, quite sadly, that I've been repeating the same basic theme with variations ever since 1985. Reading those texts one after the other, I hear myself doing something I intensely dislike: nagging. Aware that people tend to nag if they're repeatedly frustrated about being unable to modify the behaviour of others, I have had to accept that my ideas about IASPM's development don't have much effect. In fact l've started asking myself what l've been doing wrong all these years. The last two sentences in my talk at the third IASPM conference (Montréal, 1985) gave me a clue.

[I]f IASPM still exists by the turn of the millennium, or if it has not changed its name to IASM (International Association for the Study of Music), then there is either something very wrong with this "address" or something very wrong with IASPM. It would be much better if I were wrong in that case! (Tagg 1985b).

Of course I was wrong in that 'address'. Twenty-six years later I understand that youthful enthusiasm and naïve confidence had got the better of me. I have ever since been caught on the back foot by the powerful obduracy of conventional musicology and by the epistemic inertia of some popular music studies colleagues. I now have no illusions that I shall ever see music studies institutionalised in a thoroughly sane and democratic fashion. However, acknowledging naivety and accepting disappointment does not mean accepting the status quo. If it did, we would never have founded IASPM in 1981. All I've tried to do here is try and point out some areas where I think there is definite room for improvement, in much the same spirit that we argued for the foundation of IASPM in 1980 and 1981. There was room for improvement then, so why not now?

\section{Endnotes: Identities of those in Figure 2: Picture Quiz} http://www.tagg.org/xpdfs/IASPM1106Pix.pdf

\section{Answers}

Legend: ${ }^{*}=$ visible performer whose identity you are more likely to recognise from the photo than that of the invisible composer, abbreviated $\square$, whose music for the moving image you are just as likely to have heard as that of any of the visible 'acts'. Examples of film or TV titles are given in brackets after the name of each relevant 'invisible music' composers.

1. Jimi Hendrix.*

2. Hans Zimmer (Rain Man; The Lion King, Gladiator).

3. Bing Crosby.*

4. Édith Piaf.*

5. Dimitri Tiomkin (Rio Bravo; High Noon; Dial M for Murder).

6. Oum Kalthoum.*

7. Lemmy (Motorhead).*

8. Quincy Jones (In Cold Blood; Ironside; The Color Purple).

9. Nino Rota (Fellini films, The Godfather).

10. Hank Williams. *

11. A.R. Rahman (Roja; Lagaan; Slum Dog Millionaire).

12. The Beatles.* 
13. Herbert von Karajan.*

14. Carole King.*

15. Bob Dylan.*

16. Abba: Annifrid \& Agnetha.*

17. Ennio Morricone (Leone's Westerns; 1900; The Mission; The Untouchables).

18. Bernard Herrmann (Citizen Kane; Psycho; Vertigo; Taxi Driver).

19. James Brown.*

20. John Williams (Close Encounters; Superman; E.T.; Jurassic Park).

21. Elmer Bernstein (Man with the Golden Arm; The Magnificent 7; The Great Escape).

22. Dolly Parton.*

23. Max Steiner (King Kong; Gone with the Wind; Now Voyager; White Heat).

24. Joni Mitchell.*

25. Miriam Makeba.*

26. Mike Post (TV themes for Rockford Files; Magnum P.I.; Hill St. Blues; L.A. Law; Law \& Order; NYPD Blue).

27. Jerry Goldsmith (Planet of the Apes; Patton; Chinatown; Alien, etc.).

28. Bob Marley.*

29. Maurice Jarre (Lawrence of Arabia; Dr Zhivago; Witness; Dead Poets Society).

\section{References}

Gololobov, Ivan. 2011. "Post-Socialist Punk". 26 March. http://www2.warwick.ac.uk/fac/soc/sociology/rsw/current/punk/; consulted: 12.dec.11.

Hindemith, Paul. 1961. A Composer's World. Anchor/Doubleday, New York.

International Research Network, German Research Foundation. 2011. "Sound in Media Culture: aspects of a cultural history of sound." http://www.soundmediaculture.net; consulted: 12.dec.11.

Jelinek, Hanns. 1968. "Musik in Film und Fernsehen. Einige Bemerkungen zu einem aktuellen Thema." Österreichisches Musikzeitschrift, Vol. 23, No. 3.

Johnson, Bruce. 2009. 'Cultural Theory - Who Needs It?' International Conference of the Popular Culture Association and American Culture Association (PCACA), conference, Turku, Finland, July, www.tagg.org/xpdfs/TheoryWhoNeedslt.pdf; consulted 17.july.2011.

Labatos, 2011. "Celtic Music Fan", 18 July. http://celticmusicfan.wordpress.com/; consulted: 12.dec.11

Lacasse, Serge. 2000. Listen to My Voice: The Evocative Power of Vocal Staging in Recorded Rock Music and Other Forms of Vocal Expression. PhD dissertation, Institute of Popular Music, University of Liverpool, Liverpool. www.mus.ulaval.ca/lacasse/texts/THESIS.pdf; consulted 17.july.2011.

Ling, Jan. 1989. "Musik som klassisk konst. En 1700-talsidé som blev klassisk". In Frihetens former: en vänbok till Sven-Eric Liedman. Arkiv, Lund, Sweden. Pp. 171187. 
Mattelart, Armand, and Neveu, Erik. 1996. "Cultural Studies' Stories: La domestication d'une pensée sauvage?" In Réseaux no. 80 CNET, Paris. www.enssib.fr/autressites/reseaux-cnet/80/01-matte.pdf; consulted 17.july.2011.

Nattiez Jean-Jaques. 1973. "Semiologie et semiographie musicale". Musique en Jeu, no.13, pp.78-79.

Tagg, Philip. 1981. "Proposals concerning the Establishment of an International Society for Popular Music", http://www.tagg.org/articles/xpdfs/iaspprop81.pdf; consulted 17.july.2011.

Tagg, Philip. 1983. "Public Studies into Popular Music: a matter for international and interdisciplinary organisation" in Compendium \#745, p. 45, ff. (hard-copy typescript at University of Salford);

Tagg, Philip. 1985a. "Why IASPM? Which tasks?" (2nd IASPM conf., Reggio Emilia, 1983) in Popular Music Perspectives, 2, ed. D. Horn. Göteborg and Exeter: IASPM. Pp. 501-507. Also at Tagg.org. www.tagg.org/articles/xpdfs/iasptask83.pdf; consulted 17.july.2011.

Tagg, Philip. 1985b. "Address on the state of the association". www.tagg.org/articles/montreal.html; consulted 17.july.2011.

Tagg, Philip. 1987. "Report on fourth IASPM conference in Accra, Ghana", in RPM; www.tagg.org/articles/ghanarpt.html; consulted 17.july.2011.

Tagg, Philip. 1989. "Open Letter about 'Black' and 'White' Music”. Popular Music, Vol. 8, No. 3, 285-298; original version (1987) at www.tagg.org/articles/xpdfs/opelet.pdf [110717].

Tagg, Philip. 1994. "From Refrain to Rave: the decline of figure and the rise of ground". Popular Music. Vol. 13, No. 2, 209-222; original version (1993) at www./tagg.org/articles/xpdfs/pmusrave.pdf [110717]; consulted 17.july.2011.

Tagg, Philip. 1997a. "Netscope - limits and possibilities of the Internet for popular music studies". $5^{\text {th }}$ annual conference, IASPM (Australia and New Zealand), July 1997, University of Technology, Sydney. www.tagg.org/articles/xpdfs/laspOz97.pdf [110725]; consulted 17.july.2011.

Tagg, Philip. 1997. "Closing remarks', IASPM 9th international conference, Kanazawa", www.tagg.org/articles/xpdfs/kanazawa.pdf; consulted 17.july.2011.

Tagg, Philip. 1998a. "The Göteborg connection: lessons in the history and politics of popular music education and research". Popular Music, Vol. 17, No. 2: pp. 219-42; also at www.tagg.org/articles/xpdfs/gbgennct.pdf; consulted 17.july.2011.

Tagg, Philip. 1998b. "Studying music in the audio-visual media - an epistemological mess." In Music on Show: Issues of Performance, ed. T. Hautamäki and H. Järviluoma. Department of Folk Tradition, University of Tampere, Tampere, Finland. Pp. 1- 14. Also at www.tagg.org/articles/xpdfs/glasg95.pdf. consulted 17.july.2011.

Tagg, Philip. 2001a. "Popular Music Studies: bridge or barrier?".In Musica come ponte tra i popoli / Die Musik als Brückezwischen den Völkern, ed. G. Tonini. Bolzano: Libreria Musicale Italiana. Pp. 128-142. Also at www.tagg.org/articles/xpdfs/bolz9811.pdf; consulted 17.july.2011.

Tagg, Philip. 2001b. "Twenty Years After", 11th IASPM conference, Turku: www.tagg.org/articles/turku2001.html; consulted 17.july.2011. 
Tagg, Philip. .2001c. "High and Low, Cool and Uncool: aesthetic and historical falsifications about music in Europe" in Bulgarian Musicology, 2, ed. C. Levy, 9-18. Sofia: Bulgarska Akademiya na Naukute-Institut za izkustvoznanie; for very similar paper delivered at IASPM-UK/Ireland conference, University of Surrey (2000) see www.tagg.org/articles/iaspmuk2000.html; consulted 17.july.2011.

Tagg, Philip. 2007. "IASPM Pop Theory Discussion". http://tagg.org/others/IASPMtheorycorr.htm; consulted 17.july.2011.

Tagg, Philip. 2009a. Everyday Tonality. Mass Media Music Scholars' Press, New York \& Montréal. http://tagg.org/mmmsp/EverydayTonalitylnfo.htm [110717]; consulted 17.july.2011.

Tagg, Philip. 2009b. "Dominants and Dominance." http://www.youtube.com/watch?v=rWlt9ls1nms; consulted 17.july.2011.

Tagg, Philip. 2009c. "Epistemic diffraction or Integration?" http://www.youtube.com/watch?v=ITJwnh0zgVs [110723]; consulted 17.july.2011.

Tagg, Philip. 2009d. Musique et images en movement. MUL2109, cours à la Faculté de musique, Université de Montréal (hiver 2010) www.tagg.org/udem/musimgmot/musimgmot.htm [110725]; consulted 17.july.2011.

Tagg, Philip. 2011a. "Music, Moving Image and the 'Missing Majority': how vernacular media competence can help music studies move into the digital era"; keynote address, Music \& Moving Image conference, 2011-05-21, Steinhardt School, New York University; forthcoming (with PowerPoint presentation) in Film International; text only at http://tagg.org/articles/xpdfs/NYC110521.pdf [110723]; consulted 17.july.2011.

Tagg, Philip. 2011b. Scotch Snaps: The Big Picture http://www.youtube.com/watch?v=3BQAD5uZsLY [110723]; consulted 17.july.2011.

Tagg, Philip. 2011c. Epistemic diffraction or integration? www.youtube.com/watch?V=ITJwnh0zgVs; consulted 17.july.2011.

Tagg, Philip.forthcoming. Music's Meanings: a 21st- century musicology for nonmusos (provisional title). New York: Mass Media Music Scholars Press; http://tagg.org/mmmsp/NonMusolnfo.htm; consulted 17 July 2011.

Tagg, Philip and Clarida, Bob. 2003. Ten Little Title Tunes. New York \& Montréal: Mass Media Music Scholars' Press; http://tagg.org/mmmsp/10Titles.html [110722].

Tamlyn, Garry. 1998. The Big Beat - Origins and Development of Snare Backbeat and other Accompanimental Rhythms in Rock'n'Roll. PhD Dissertation, 2 volumes, Institute of Popular Music, University of Liverpool. http://www.tagg.org/others/TamlynPhD.html; consulted 17.july.2011.

\section{Discography}

Monty Norman. 1962. "Theme from Dr No" (a.k.a. James Bond Theme), The Best of Bond, United Artists UAS 29021, USA. tagg.org/audio/DrNoBondVinyl.mp3; see also www.itunes.apple.com/us/artist/john-barry-orchestra/id133904310; also DVD Dr No (NTSC) MGM 0-7298-4528-5. consulted 17.july.2011. 